\title{
FEUDALISMO Y SEÑORIALISMO EN LA AMÉRICA ESPAÑOLA COLONIAL
}

Joaquin Rodriguez Suro

Numerosas veces hemos oído sobre "el legado feudal" español en América. ¿Qué de cierto hay sobre tal afirmación? En el presente artículo nos proponemos indagar sobre dicha cuestión.

Empecemos por establecer una distinción entre feudalismo y señorialismo, conceptos que, aunque relacionados, no son iguales. Feudalismo, según muestra Marc Bloch en La societé féodale, es el sistema político en que, vía nexos de dependencia personal basados en comunes obligaciones de defensa y protección entre señor y vasallo (altos miembros de la clase militar, por consiguiente), y por medio del feudo, hay una descentralización masiva del poder público. En otras palabras, la esencia del feudalismo es el pacto personal entre altos miembros de la clase militar, los caballeros que pueden costear el precio de un caballo, artículo de lujo en la Alta Edad Media, y toda la impedimenta de lanzas, armaduras, etc. Señorialismo, por su parte, y también siguiendo al ilustre Marc Bloch, es la relación de dependencia económica y jurídica entre un señor y los campesinos que cultivan sus tierras. Generalmente se confunden ambos términos cuando se habla de "feudalismo" en América. Se explica la confusión, ya que las tierras señoriales pueden ser al mismo tiempo tierras feudales, es decir, que estén dentro del feudo que el señor ha cedido a su vasallo militar para que éste pueda sustentarse y esté listo, por consiguiente, para socorrer a aquél en cualquier trance. Pero pueden haber tierras señoriales cuya tenencia no implique la descentralización de poderes típica del feudalismo. Esas tierras abundaron en la Península Ibérica, donde, según autores como Juan García de Valdeavellano, en su Historia de España y Jaime Vicens Vives en su Historia de España y América: social y económica, no hubo feudalismo más que en Cataluña. En España, debido a la lucha centenaria contra los musulmanes, el poder del rey nunca se diluyó durante la Alta Edad Media como ocurrió en otras regiones de Europa, incluyendo a Cataluña. Las tierras señoriales españolas, en términos generales, no constituyeron feudos que debilitasen el poder del rey para ordenar directamente a sus súbditos. A tin en los casos en que se concedieron señoríos con jurisdicción judicial por parte del señor, el rey siempre conservó el derecho de aplicar la justicia en ciertos casos. Obras del Siglo de Oro, como El mejor alcalde, el rey y Fuenteovejuna, de Lope de Vega, van al meollo del asunto. En la primera, Lope nos muestra cómo el mejor juez, el rey (recordemos que "alcalde" es término judicial y administrativo en la época, ya que no existía separación de poderes tal como los conocemos hoy en día) entra a un señorío para 
aplicar justicia a un campesino cuya novia fue ultrajada por el señor. En Fuenteovejuna el comendador de una Orden Militar agravia a todo un pueblo burlándose de sus mujeres. El rey perdona al pueblo el asesinato del comendador $y$, dato centralizador, hace que el señorio deje de pertenecer a la Orden Militar y lo convierte en realengo. El genial Lope, gran sostenedor de la monarquia centralizada, capta la esencia democrática de la facultad real de desagraviar a los campesinos avasallados por sus señores. Lope muestra claramente cómo no hubo feudalismo en España, sino un señorialismo menos severo que el europeo. El literato, mediante sus obras imaginativas, ha sabido captar bien la esencia del espíritu político de la Edad Média española.

Sorprende ver autores hispanoamericanos, como A. René Barbosa-Ramírez, en $L a$ estructura económica de la Nueva España, y Enrique Semo, en Historia del capitalismo en México, terriblemente ignorantes de la situación real de la Península Ibérica durante la Edad Media y continuar hablando del "legado feudal" español. Es que, estudiantes que fueron en universidades francesas y alemanas, dejaron de tomar contacto con las raíces hispánicas de su patria, México, y no estudiaron a los autores españoles que les ilustrarían sobre la situación real de la España medieval. Bebieron fuentes europeas que no hablaban de la particular situación ibérica y si las leyeron cerraron sus mentes a la realidad, para poder continuar achacándole a España los orígenes de los males de México.

Explicada la distinción entre ambos conceptos, veamos su presencia, si alguna, en la América española colonial. Analizaremos varios aspectos del régimen colonial español: la vida laboral, la vida religiosa, la vida política y la vida económica.

\section{La vida laboral}

Cuando los españoles llegaron a América se sintieron ennoblecidos por el hecho de ser blancos y poseedores de una cultura "superior" a la indígena. Como ha estudiado magistralmente Guillermo Céspedes del Castillo en la Historia de España y América: social y económica, en América nunca hubo una nobleza formal al estilo de la europea. América sirvió de esa forma para los blancos como elemento nivelador, democratizándolos en una misma casta, separándolos de los negros, mulatos y mestizos y de los indios. Eran superiores a los no-blancos. Los reyes españoles, escaldados con las luchas terribles que sostuvieron contra los nobles durante los siglos XIV y XV, idearon mantener a América aséptica en cuestiones de nobleza formal. Por eso nunca hubo, en términos generales, una nobleza formal en América. Por otro lado, el afán ennoblecedor español al entrar en contacto con otras razas hizo con que aun los nobles formales no pudieran gozar de los privilegios jurídicos y económicos que tenían en España, tal como exención de impuestos y procedimientos procesales especiales por el hecho de ser nobles. En la América colonial, distinto a España, los blancos eran iguales frente a la ley frente al apartato hacendístico gubernativo. ¿Por qué la diferencia entre España y América? Como América era considerada tierra utópica donde todo español encontraría su riqueza inmediatamente, vía la aventura fácil (valga recordar que durante los tres siglos de colonia América fue llamada "las Indias", recordando la riqueza mercantilista, factorial, que fue el propósito original de la primera expedición descubridora colombina), la raíz democrática castellana se potenció acá, desarrollándose aún más que en España. Si recordamos las pequeñas propiedades que vía la presura se forjaron en las tierras reconquistadas a los musulmanes 
desde el Duero al Tajo y las relacionamos con la institución medieval hispánica del caballero villano, plebeyo que por su riqueza podía comprar un caballo y servir al rey en igualdad de condiciones con los nobles, podremos comprender por qué la expectativa de una riqueza inmediata ennoblecería aún más al inmigrante español en América. Así como el caballero villano se equiparaba a los nobles en algunos de sus privilegios (aunque no en todos), gracias a su alianza con el rey, el inmigrante español se unió a éste en su repudio a la constitución de una verdadera nobleza formal en Indias. En ambos casos los reyes fueron racionales y admitieron su necesidad de otra clase, equiparada a la nobleza en muchos aspectos, para conseguir sus fines. En el caso de la Alta Edad Media, la lucha contra el musulmán. En el caso indiano la ojeriza de ver en América una nobleza que le hiciera la guerra al rey, como en los siglos XIV y XV en la Península Ibérica. En ambos casos los plebeyos hicieron uso de la democratización anhelada por los reyes, sintiéndose los iguales de los nobles. Es lo que en España vemos en el teatro del Siglo de Oro, en que los villanos, tal como en el Peribáñez de Lope de Vega y en El alcalde de Zalamea de Calderón de la Barca, se sienten los iguales de los nobles. Claro está, lo que en España es sentimiento de orgullo personal, probablemente asociado al hecho de sentirse cristianos viejos, es decir, no contaminados con sangre de moro o judio, como señala Américo Castro en La realidad histórica de España, en América es pura legalidad. América es, pues, el desarrollo de la idea democrática castellana. Sentimiento democrático que impide que los conflictos de clases en España produzcan la ascensión política y económica de una clase burguesa distinta de la nobleza y en franca contraposición con ésta, como ocurre en otros paises europeos. La mayor movilidad social existente en España hará que tanto los caballeros villanos del campo como el patriciado urbano de la ciudad no se sientan muy distintos de la nobleza. Por el contrario, adquirirán la mentalidad aristocrática de que lo bonito, lo anhelado, será la vida del señorito que vive de rentas, sin manchar sus manos con trabajos manuales, ni preocuparse con la producción de la riqueza material. Los que no tengan riquezas (recordemos el dictado: "padre comerciante, hijo noble, nieto pordiosero") pavonearán su pobreza, ocultándola, tal como lo vemos en El buscón de Quevedo y El lazarillo de Tormes. Pero no habrá en España hasta fines del siglo XVIII una clase burguesa cuya mentalidad productiva y economizadora se contraponga al afán meramente rendístico y consumista de los nobles.

A diferencia de países como Holanda, Inglaterra y Alemania, en que el espíritu burgués se desarrollará precozmente, dejando atrás la primitiva etapa burguesa corporativa en que se pretendía eliminar la competencia de precios o de técnicas productivas, y alcanzando finalmente la etapa del capitalismo industrial en que el hombre se valorizará absolutamente por su productividad material, la sociedad española mantendrá el humanismo católico de que la sociedad debe ser estabilizada mediante la aceptación por los hombres de su naturaleza estática. En aquellos países europeos habrá más cambios sociales y económicos que en España, desde el siglo XVI al XVIII, debido a la cuña burguesa que pretenderá trastrocar la estabilidad socio-económica. Paradójicamente, la mayor lucha de clases existente en otros países europeos desarrollará precozmente en ellos las bases antropológicas y culturales del capitalismo industrial, mientras que la mayor democracia existente en España hará que la sociedad española se muestre más impermeable a los cambios. ¿Por qué esa paradoja? Es que la democracia española de los siglos XVI al XVIII no es el resultado de un compromiso bilateral entre nobles y 
burgueses en que ambos cedan terreno para poder vivir en paz. Por el contrario, la democracia española es el resultado de una aceptación unilateral por parte de los burgueses de la superiordidad de la vida nobiliaria, rendística, sobre la vida del comerciante que trata de impulsar el intercambio de riquezas y de la del artesano productor. Controlada mentalmente la sociedad española por los nobles, no hubo en ella los cambios que ocurrieron en otros paises europeus.

¿Qué efectos antropológico-culturales tuvo en la sociedad española esa carencia de un espíritu burgués diferenciado y vigoroso durante los siglos XVI al XVIII? Gracias a la estabilidad socio-económica que gozaron las estructuras sociales españolas durante esas centurias, se preservó en España el verdadero espíritu católico de compasión por el prójimo, de sentir al prójimo como una extensión de uno: la presencia del prójimo como necesaria para el bienestar de uno. Otras sociedades europeas en que predominó el espíritu burgués se hicieron, por el contrario, menos católicas y el protestantismo, aliado al espíritu burgués, separó al individuo de su sociedad, aislándolo en su interpretación particular de la Biblia, alejándolo de la interpretación colectiva que necesitaba de un instrumento social, la Iglesia, para poder evaluar efectivamente el mensaje divino. En esos países de mentalidad burguesa y protestante, la finalidad de la vida no fue más, como en la humanitaria España católica e hidalga, vivir de acuerdo con unos valores preestablecidos, tanto en la vida religiosa como en la vida económica. Por el contrario, en los países burgueses protestantes el individuo no tenía un sitial preestablecido en la sociedad, sino que tenía que forjárselo mediante su esfuerzo individual. Para salvar su alma no bastaba cumplir con su función nata dentro de la sociedad. Mientras más rico fuese más garantías tenía de que era uno de los predestinados por Dios para ganar la gloria del Paraíso, y al mismo tiempo mejoraba su situación social como burgués diferenciado del noble. Tanto en el aspecto religioso como en el socio-económico, el burgués europeo se sentía aislado, diferenciado de los demás grupos sociales. El rico plebeyo español, por el contrario, se ennoblecía, integrándose dentro de la casta nobiliaria, la cual lo recogía en su seno, democráticamente. El villano español se sentía el igual de los nobles, el burgués europeo se sentía frustrado porque era muy distinto de los nobles y éstos continuaban teniendo el poderío político.

De manera que la mayor democracia existente en España y la carencia de una verdadera lucha de clases durante los siglos XVI a XVIII preservaron en tierra española el espíritu católico de compasión frente al prójimo. Es por eso que vemos cómo en la España contemporánea hay una mayor aceptación del prójimo que en países como Holanda, Alemania e Inglaterra. La sociedad española es mucho más personalista que la de esos otros países donde cundió el protestantismo y el espíritu burgués. Aquellos países tienen una estructura antropológico-cultural de mayor frialdad en el trato entre los seres humanos, en comparación con España. Es que el espíritu protestante burgués ha desarrollado en esos países la valoración del prójimo como un medio y no como un fin en sí. Recordemos la ética kantiana en su Crítica de la razón práctica: aboga Kant por la excelencia ética de cumplir las leyes morales no por la simpatía que podamos tener por ellas, ni por el bienestar que puedan traernos, sino por la obligación de cumplirlas. La ética kantiana, estrechamente ligada al espíritu protestante luterano, elimina completamente la subjetividad humana en la valoración de las leyes morales. ¿Quiere eso decir que Kant elimina totalmente al individuo en su libro sobre ética? Ni mucho menos. Por el 
contrario, para Kant las leyes morales deben ser autónomas. El individuo no debe aceptar leyes morales que sean heterónomas, que tengan un origen que no parta de su propia conciencia. Pero al mismo tiempo, gracias al racionalismo, esas leyes autónomas, que parten del individuo, serán universales. Pues el individuo deberá aceptar como válidas únicamente leyes morales que puedan ser aplicadas universalmente. De esa forma trata Kant de conciliar el individualismo protestante de interpretación de los dictados divinos con el racionalismo objetivo, válido para todos los seres pensantes. Lamentablemente, la hermosa ética kantiana, que preconiza valorar al prójimo como un fin y nunca como un medio, no se cumple en los países protestantes burgueses. El individualismo extremo, efecto de la conjunción del protestantismo y del espíritu burgués de competencia incansable, ha producido en esos países y en su heredero Estados Unidos la infravalorización intrínseca del prójimo. La vida se ve en esos países como una lucha continua en que sólo sobrevivirán los más capaces en derrotar los anhelos de los demás en subir de posición en la escala social. Esa atroz lucha se exacerba en Estados Unidos, especialmente en luga ${ }^{\circ}$ s como Nueva York, en que el aislamiento morboso de los seres humanos llega al extremo de que todos precisan de ir al psiquiatra y pagarle carísimo para tener a un ser humano que instantáneamente compadezca los infortunios de uno, como se ve en la película de Woody Allen "Novio neurótico, novia nerviosa" ("Annie Hall"). En la Inglaterra actual, por otro lado, los rasgos alienantes de la estructura burguesa protestante de la sociedad inglesa están siendo atenuados por un socialismo democrático que le provee al individuo su sitial acogedor dentro de la sociedad y por una sana política de los ingleses de olvidarse de la ganancia y trabajar menos para disfrutar de la vida, en franco desacuerdo con el espíritu ganancial burgués, que sí rige desenfrenado en Estados Unidos, donde lo único considerado verdaderamente importante es cuánto uno gana.

Claro está que no hay que olvidar que la sociedad española es extraordinariamente interesante, debido precisamente a su pasmoso alto grado de contradicciones intrínsecas. Todo se personaliza. Pero los españoles pueden ser muy fríos y hasta increíblemente rudos con extraños. No es hasta que conocen a uno por un tiempo que se aflojan y lo acogen con ese extraordinario calor humano que pueden generar si se lo proponen. Claro está, una sociedad tan personalista y tan subjetivista como la española nos muestra la paradoja de la variación súbita de la valoración que otros tienen sobre nosotros. Quien nos trató con suma amabilidad un día, porque se sentía muy feliz ese día y fuimos partícipes gratuitos de ese bienestar general que esa persona sentía, otros días nos puede tratar con relativa indiferencia. Si discutimos acaloradamente con un conocido español, llevándole la contraria en cualquier discusión, no importando lo anodino que sea el tema, veremos la inmediata retirada de la valoración positiva que esa persona tenía sobre nuestras personas. Veremos en Madrid empujones y codazos aplicados a diestro y siniestro, sádicamente, en el metro. Veremos miles de personas caminando anárquicamente, sin mirar para el frente ( ${ }_{i}$ a veces incluso leyendo libros!), llevándose a todas las personas que se pongan en su camino. ¿Disculpas por el tropiezo? La palabra "perdón" no aparece en el lenguaje madrileño. Bastantes desconcertados y halagados se sienten cuando un extranjero pide perdón por algún tropiezo, ya que no están acostumbrados a eso. Hay incluso extremos en que señoras (son las peores) se irritan por un tropiezo que es culpa de ellas, ya que no miran por donde caminan (diría Angel Ganivet en Idearium español: es ideal de todo español es que haya un solo artículo en la constitución: "este español está autorizado a 
hacer lo que le dé la gana.”) y lanzarán improperios contra uno. Pero, ( ¡ contradicciones de la sociedad personalista!) las mismas señoras que lanzaban codazos y empujones en el metro e improperios en los tropiezos accidentales, se inclinarán para darle a uno una moneda que uno dejó caer sin darse cuenta o ayudarán a un ciego a cruzar la calle. Es que los españoles pueden ser seres maravillosos cuando se lo proponen y ogros horripilantes cuando quieren. Todo gira en torno del ánimo individual, que es completamente subjetivo. Se hipervaloriza al yo, frente al universo. Paradójicamente, una sociedad tan amena y tan alegre como la española también es una sociedad dura y triste, dependiendo del ánimo individual del momento. Las mamás tratan rudamente a sus chiquillos, dándoles duramente en plena calle y después pegándoles de nuevo porque lloran. Les exigen que se muevan rápidamente, pero si se muestran demasiado vivos e inquietos les pegan para que se calmen. Pueden incluso llegar a darles órdenes contradictorias, como la mamá del parque del Retiro en Madrid que le gritó a su nene: "Corre sin correr."

La contrapartida de la hipervalorización del yo, del extremo subjetivismo, es, pues, la regencia del arbitrio variable e inconstante sobre la ley objetiva. Se valorizan positivamente a las personas y a las instituciones siempre y cuando estén de acuerdo con lo que uno piensa. En el momento en que dejen de pensar como uno se convierten en enemigos de la expansión de nuestro yo en el universo. En España la vida política es extremadamente peligrosa, ya que no pueden ser amigos quienes no piensan de la misma forma. El subjetivismo extremo crea la intransigencia que lleva muchas veces a la intimidación física y al asesinato político y hasta la guerra civil. En los países europeos burgueses y protestantes y en Estados Unidos, por el contrario, la discusión política no acarrea la violencia automática, ya que esas sociedades son menos personalistas que la española y saben separar las relaciones personales y la discusión objetiva.

Pues bien, hecho este preámbulo sobre las características antropológicas de la sociedad española actual, volvamos al tema de la Hispanoamérica colonial. No se perderá la divagación, ya que creemos, con Unamuno, que existe una intrahistoria en la vida de los pueblos en que se mantienen relativamente incólumes las estructuras antropológicoculturales que les dan consistencia y continuidad histórica a los pueblos, manteniendo su identidad frente a los cambios socio-económicos. Por otro lado, aunque los países hispanoamericanos tienen unos rasgos culturales diferentes de los españoles, continúan teniendo una cultura muy similar a la española, sobre todo si se compara a los hispanoamericanos con pueblos muy diversos, como el alemán o el inglés. Obviamente los hispanoamericanos, aunque distintos de los españoles, se parecen mucho más a éstos que a los alemanes o a los ingleses.

La mayor democratización existente en España, por tanto, impele a los españoles en América a tratar de alcanzar la vida nobiliaria, tratando de que otros trabajen para ellos. Por eso al llegar a América querían que los indígenas trabajasen para su enriquecimiento nobiliario. Por otro lado, el Estado español era profundamente católico y encontraba como justificativa ideológica de la conquista de América, no razones mercantilistas, sino la evangelización de los indios. Obviamente que aquéllas estuvieron siempre presentes en la relación entre España y sus colonias americanas, pero no eran lo más importante en la escala de valores del Estado español. En relación con el espíritu nobiliario está el espíritu quijotesco de desprecio por lo meramente material y la idealización de una búsqueda de engrandecimiento del orgullo personal mediante acciones que vistas a la luz del frío 
utilitarismo pueden ser consideradas francamente inoportunas, si no descabelladas. El Estado español se convierte, por consiguiente, en idealista, y desea, al igual que Don Quijote en tierras manchegas, informar la moral en los territorios americanos. Haciendo caso omiso del deseo de los inmigrantes españoles, comenzando por el propio Colón, de esclavizar lisa y llanamente a los indios, el Estado español se convierte en protector de éstos. Los indios son declarados hombres libres, aunque, reconociendo el Estado sus condiciones culturales y antropológicas diversas de las de los españoles, los equipara a los rústicos y menores de edad del derecho castellano, según nos informa José M. Ots Capdequí en su El estado español en las Indias. En toda la historia colonial hispanoamericana se verá un esfuerzo descomunal por parte del Estado español de reglamentar las relaciones entre los indios y los españoles y también posteriormente entre aquéllos y los criollos, mulatos y mestizos. El mejor alcalde, el rey, será garante de la libertad de los indios. La protección de los reyes a las clases desafortunadas frente a los desmanes de los nobles se extenderá en América a la protección de los indios frente a los nobles de facto, los españoles, y sus descendientes, los criollos. No hay solución de continuidad marcada entre España y la Hispanoamérica colonial. Esta es el lógico desarrollo de tendencias que ya estaban presentes en la historia española. Aunque distinta de España, Hispanoamérica será su heredera, sin cortes tajantes entre ellas. Dentro de la casta blanca, Hispanoamérica será más democrática que España, ya que en aquélla no existirá la nobleza formal que informó las relaciones de clases en ésta. (Con la excepción durante la colonia de la preferencia para los altos cargos burocráticos, militares y eclesiásticos de peninsulares sobre los criollos.) Claro está, la distinta configuración racial y cultural de los grupos demográficos hispanoamericanos contribuirá a que en Hispanoamérica haya una desigualdad profunda que no existía en España: la constitución de castas jurídicas en que el color de la piel, aunado con la procedencia histórico-cultural jerarquizaba a la sociedad hispanoamerica en compartimientos estancos. Por fortuna, la carencia hispánica para encontrar repugnancia a la mezcla de sangre permitió que, gracias al mestizaje, se fuera diluyendo paulatinamente, en gran medida, la estratificación demográfica en castas cerradas. Pero aún así vemos que en países donde todavía se conserva pura gran parte de la población indígena, como en México, Guatemala, Ecuador, Perú, Bolivia, hay una profunda desigualdad social basada en el color de la piel y sobre todo en la procedencia histórico-cultural: los culturalmente indios son despreciados por los mestizos y los blancos. En países en que la mezcla de razas se perfeccionó más, como en Puerto Rico, constituyéndose una sociedad básicamente mulata, con pocos blancos o negros puros, no existe hoy en día la herencia de las castas coloniales. Tampoco existe en países como Uruguay y Argentina, en que la voluminosa inmigración europea constituyó grupos demográficos preponderantemente blancos.

La reglamentación colonial de las diversas castas es un legado de la convivencia centenaria entre españoles y musulmanes. No existe ningún abismo cultural ni histórico entre España e Hispanoamérica. En América se potencian tendencias existentes en la historia española. Los españoles que durante centurias se acostumbraron a la separación jurídica entre musulmanes y mozárabes o entre españoles y mudéjares, encontraron sumamente natural establecer castas que reglamentaran la separación jurídica entre blancos, indios y mulatos y mestizos. Claro está, sin hablar de los negros importados de Africa que, por su condición de esclavos lógicamente estarían separados jurídicamente de los demás integrantes de la sociedad colonial. 
De manera que, una vez decretada la libertad del indígena americano, había que conciliar esa libertad con los deseos del español de que otro trabajara para su engrande. cimiento nobiliario. ¿Cómo se hizo? Se introdujo en América la institución de la encomienda. ¿En qué consiste la encomienda? En sus comienzos en las Antillas, según nos informa Demetrio Ramos Pérez en su Historia de la colonización española en América, la encomienda era una esclavitud disfrazada. El indio encomendado tenía que trabajar para el encomendero español sin ningún límite de tiempo y sin ningún salario. Inclusive las mujeres tenían que trabajar. Posteriormente se prohíbe el trabajo de las mujeres y los niños, limitándose al mismo tiempo el período laboral y decretándose un salario a ser percibido por los indios. Cuando la institución se transfiere al continente americano, se mejora notablemente la situación del indígena, gracias sobre todo a la actitud contestataria de clérigos como Montesinos y Bartolomé de las Casas. El Estado español, idealizador, responderá a las críticas de esos denodados clérigos defensores de los indios, ablandando el rigor con que los españoles podían tratarlos legalmente.

La encomienda mejorada, que finalmente dura hasta el siglo XVIII, cuando será abolida, consiste en un tributo, únicamente un tributo, que el encomendado debía pagar al encomendero. Ese tributo sería determinado teniendo en cuenta los tributos que los indios pagaban antiguamente a sus señores indigenas, para que el Estado español no se viera como más demandador que aquéllos. Se eliminan totalmente en la encomienda mejorada, por tanto, las prestaciones de servicios personales. Representa de tal suerte la encomienda una expropiación indirecta del trabajo indígena, como diría Enrique Semo en Historia del capitalismo en México. ¿Qué justificativa jurídica se da a la encomienda mejorada? Como los indios eran considerados súbditos libres de la Corona española, debian pagarle un tributo al rey. Este, a su vez, les cedía a los encomenderos esos tributos, para que pudieran mantenerse, reconociendo el Estado sus anhelos de vida nobiliaria. En contrapartida a la tenencia de la encomienda, los encomenderos debían prestarle servicio militar al rey y pagar un cura que adoctrinase a los indios en la religión católica. De manera que desde el punto de vista del Estado español la encomienda tendría como finalidad: asegurar la libertad del indígena, reglamentando su relación con el encomendero, asegurar la lealtad de los españoles que fueran a América, incluyendo su servicio militar, y finalmente, encontrar un mecanismo mediante el cual curas doctrineros pudieran subsistir para emprender la evangelización de los indios. El encomendero podría vivir de rentas como un noble. Y el indio tendría su libertad jurídica, pagando un tributo que ya estaba avezado a pagar en la época pre-colombina.

¿Es la encomienda mejorada una institución feudal o señorial? Obviamente, la encomienda nos trae a la mente reminiscencias del feudalismo europeo. Pues podemos relacionar la encomienda con el tipo de feudo en que el rey cedía un derecho público al feudatario. En el caso de la encomienda el tributo sería el derecho público cedido por el rey. También el hecho de que el encomendero estuviese obligado a prestar un servicio militar, pagadero con la tenencia de la encomienda (el feudo) subraya la identificación entre encomienda y régimen feudal. El adoctrinamiento de los indios también podría ser considerado como parte de la búsqueda de una seguridad, en la teoría de que, una vez cristianizados, los indios serían menos belicosos y, por tanto, representarían un menor peligro para los españoles. Así como en Europa el feudalismo surgió en una época en que los reyes no podían garantizar, por sí mismos, la seguridad pública, debiendo, por 
consiguiente, ceder atributos públicos para que otros señores se ocupasen de garantizar la seguridad general, la encomienda surgiría debido a la debilidad del rey de España para proveer la seguridad en las tierras americanas por su propia iniciativa. Pero falta en América otro de los orígenes del feudalismo europeo: la carencia de un vigoroso comercio internacional, como nos relata Henri Pirenne en Historia económica y social de la Edad Media. La atrofia del comercio internacional europeo durante la Alta Edad Media facilitó el ascenso del feudalismo, ya que los señores tenían que consumir en el lugar lo que producían sus feudos; siendo limitadas las relaciones económicas fuera de las microregiones feudales, había una correspondencia entre la economía básicamente localista y el feudalismo político. En América, por el contrario, siempre existió un vigoroso comercio internacional, desalentando, por consiguiente, el surgimiento de un feudalismo político al igual que el europeo. Claro está, por otro lado siendo América un desarrollo de la historia española, no podía existir feudalismo acá cuando no lo hubo en Castilla. La encomienda, a pesar de tener rasgos feudales, no es una institución feudal. Le falta la esencia del feudalismo que es la descentralización masiva del poder público. Si bien es cierto que el rey de España cedió un poder público, el de percibir tributos de los indios encomendados, a los encomenderos, no les cedió ni un ápice de sus prerrogativas jurídicas. El encomendero no tenía ninguna jurisdicción sobre los indios encomendados. La encomienda, por tanto, no es una institución señorial, puesto que la jurisdicción plena se la reservaba el rey. No es, de tal suerte, un feudo territorial, máxime si pensamos que las tierras en que se radicaban los indios encomendados eran de ellos y no de los encomenderos.

Si bien nos recuerda rasgos de los feudos en que se cedían derechos públicos, la encomienda no puede ser considerada como una institución feudal. Para poder clasificar una institución dentro de unas coordenadas comparativas, hay que llegar a un consenso sobre lo que constituye la esencia del modelo con que se pretende comparar. Si falta alguna de las características esenciales del modelo, la institución investigada puede ser clasificada como parecida con el modelo, pero no podrá ser identificada con él. Podemos concluir de tal suerte sobre la encomienda indiana que tiene rasgos feudales, pero que no es una institución feudal. No podrá ni ser clasificada como semifeudal, ya que no es ni una institución señorial. ¿Qué es, por tanto? El análisis de la encomienda indiana nos lleva a la conclusión de que es una institución especialísima, típicamente americana. Aunque tiene sus raíces en Europa no es igual a ninguna institución europea. La encomienda es el resultado del desarrollo de la historia española, una sabia aplicación por parte de los españoles de las lecciones aprendidas durante el transcurso de su historia a la nueva realidad americana que se desplegaba frente a sus ojos. Como ya analizamos anteriormente, vemos en la encomienda la potenciación de la democratización española, así como la idealización por parte del Estado español de sentimientos cristianos de justicia hacia los indios.

Veamos ahora otra institución colonial: la mita o cuatequil, trabajos forzosos que los indios, fueran encomendados o no, tenían que prestar a los españoles, por un salario que era menor al equivalente que tendría que desembolsar el empresario español para obtener un asalariado libre que hiciera el mismo trabajo que el indio mitayo. La mita, hay que mencionarlo, estaba férreamente controlada por el Estado español, que estipulaba el tiempo de trabajo, quiénes tendrían que servir y qué empresas españolas podrían beneficarse del trabajo mitayo. Por otro lado, la mita, por lo menos teóricamente, no era nada 
gravosa para el indigena, ya que se limitaba muchísimo el tiempo de trabajo: en México una semana de trabajo tres veces al año; en Perú cuatro semanas de trabajo cada siete años. Asimismo la proporción de indios que cada pueblo indígena tendría que remitir de una vez era bajísima: como $4 \%$ en México y $7 \%$ en Perú. Y todo eso por un salario, que aunque bajísimo, era mucho mejor que trabajar gratis. Vemos en la mita otra institución especial de América. Esta vez la reminiscencia del señorialismo europeo es muy débil. Estando la jurisdicción plena en manos del Estado, no es equivalente, por tanto, al trabajo gratis que tenían que prestarle a sus señores en Europa los habitantes de las tierras señoriales. Esta es otra institución que también conocían los indígenas pre-colombinos, de manera que no tenía por qué sorprender a los indios.

Los esclavos negros, por su parte, no gozaron de la protección que el Estado les otorgó a los indios. Si bien se hicieron leyes que trataban de mitigar el rigor del trato, no se fiscalizó su cumplimiento con el tesón con que, para orgullo de España, lo hizo el Estado con respecto al tratamiento dado a los indios. Es comprensible que en una sociedad tan contradictoria y $\tan$ personalista como la española se haya dado la paradoja de un desinterés por la protección del negro al lado de un ingente afán por proteger al indio. Como los españoles no son consistentes en sus razonamientos, viéndolo todo negro o blanco, de acuerdo a sus simpatías o antipatías, no es de extrañar que haya existido esta contradicción en el trato dado a negros e indios. Simpatizaron con los indios, los trataron bien. Para ellos los negros eran antipáticos, por lo tanto no se importaron de esclavizarlos lisa y llanamente. Por supuesto que la institución de la esclavitud del negro no es ni feudal ni señorial por definición, ya que los negros esclavos no eran considerados seres humanos, sino objetos materiales cuyos dueños tenían la facultad exclusiva de determinar su forma de vida, con la salvedad de leyes generales que trataban de mitigar el maltrato. El régimen esclavista es, por tanto, jurídicamente una forma del derecho privado de propiedad y no una valoración del tratamiento dado a seres humanos. No puede de tal suerte ser ni feudal ni señorial, ya que los negros esclavos no eran jurídicamente seres humanos y aquellas categorías versan exclusivamente sobre las relaciones inter-humanas. El señor de esclavos, por su parte, no tenía ninguna jurisdicción sobre los hombres libres que trabajaran bajo su mando. No tenía, por tanto, ninguna facultad señorial ni feudal. La jurisdicción del Estado caía directamente sobre los hombres libres que trabajaban para el señor de esclavos, sin pasar por la mediación de éste. Y con respecto a los esclavos negros el Estado tenía cierta jurisdicción sobre ellos, mitigando el poder absoluto del señor de esclavos de determinar el destino de su propiedad. Podemos concluir, por lo tanto, que la institución de la esclavitud negra no es ni feudal ni señorial. Tampoco es una institución típicamente americana, como sí lo fueron la encomienda y la mita. Es un verdadero trasplante de la esclavitud europea, ya que la esclavitud que conocieron los indígenas era completamente diferente. La esclavitud en la sociedad azteca, por ejemplo, según nos dice Jacques Soustelle, en La vida cotidiana de los aztecas en visperas de la conquista, podía ser incluso volurtaria: un individuo se vendía a otro, para disfrutar del dinero de la compraventa y para vivir una vida relativamente suave. La diferencia era tan grande que el propio Estado español la reconoció, prohibiendo que se rescatasen esclavos indígenas, ya que el trato que los españoles les daban a los esclavos era muchísimo más riguroso que el que los indios les daban. 
El trabajo de los asalariados libres, a su vez, también representa un trasplante de formas laborales europeas. En América también existió la institución gremial, calcada de moldes europeos, aunque no pudo llegar a acaparar la exclusividad del trabajo artesanal, como en Europa. Como con la excepción de normas laborales dictadas por el gremio los trabajadores libres estaban sujetos a la jurisdicción del Estado, el gremio no es una institución señorial ni feudal.

Hemos visto que en la vida laboral de la Hispanoamérica colonial no existió ni feudalismo ni señorialismo. Aquélla estaba regida por un Estado paternalista e idealizador, cristiano, que quería conciliar las diferencias entre los diversos componentes de la sociedad colonial. Se buscaba el equilibrio social para evitar las luchas de clases. El Estado tendía a buscar la paz entre indios y españoles, entre esclavos negros y sus señores, entre los artesanos y sus clientes. Se hicieron numerosísimas leyes reglamentando el trabajo de los asalariados, para protegerlos de la explotación patronal. El Estado centralizado reunía dentro de sí amplísimos poderes que buscaban la reconciliación cristiana entre todos los integrantes de la sociedad colonial. El tan denigrado y vilipendiado régimen colonial español, con todas sus fallas e imperfecciones, fue un exitoso intento de llevar a la tierra americana la operatividad del mensaje caritativo del cristianismo. España puede sentirse orgullosa de haber podido mantener, con las entendibles imperfecciones en el contraste entre la teoría y la práctica, un régimen colonial relativamente blando y humano, que fue la potenciación de la democracia española medieval. Aun en un país como México, en que la Conquista española aún no ha sido perdonada, vemos que después del desastre del liberalismo decimonónico, la Revolución Mexicana de 1910 se vuelca a las sábias lecciones de convivencia humana del Estado colonial español. El intento de los liberales mexicanos durante el siglo XIX de cortar todas las amarras con el pasado colonial mexicano fue perjudicial para el pueblo mexicano, cuya situación vivencial empeoró considerablemente después de la independencia.

\section{La vida religiosa}

Durante toda la época colonial hispanoamericana, rigió un patronato en que el Estado fue consistente, en el plano de las instituciones religiosas, con su política de centralización de poderes. Al igual que en el plano laboral, en el orden religioso el Estado actuó como elemento modificador de las relaciones entre las instituciones y los individuos que tenían que ver con ellas de una forma u otra. Al igual que en el plano laboral, en el orden religioso los detentores del poder institucional, en el primer caso encomende ros o empresarios, en el segundo los clérigos, lucharon de diversas formas por liberarse de los organismos rectores del Estado y ganar una mayor independencia de acción. En ambos casos el Estado tuvo que conciliar los intereses estat ales con dichas presiones. $\mathrm{Y}$ en ambos casos no hubo ni feudalismo ni señorialismo en las instituciones, debido a la ingerencia del poder central en ellas. Por otro lado, hay una mayor simbiosis en la relación entre la Iglesia y el Estado colonial español que entre éste y los legos particulares. Es comprensible que así fuera, ya que el Estado español se vanagloriaba de su catolicismo e hizo un ingente esfuerzo porque éste informase su política hacia los habitantes de las Indias, como ya apuntamos anteriormente. Si el Estado tenía cierto control sobre la Iglesia, ésta, a su 
vez, era el organismo de donde salía toda la ideología justificativa de la conquista y colonización de América. Hay una verdadera simbiosis entre la Iglesia y el Estado en la Hispanoamérica colonial.

\section{La vida política}

En conjunción con la carencia de feudalismo y señorialismo en la vida laboral de la Hispanoamérica colonial, tampoco existieron, más que en contados casos en los comienzos de la colonización americana, elementos políticos señoriales. El régimen colombino, por ejemplo, era palmariamente señorial, debido a toda la amplia jurisdicción primaria que ostentaba Colón y que era transmisible a sus herederos. Pero aun en ese caso no había feudalismo, ya que el rey podía ordenar directamente a sus súbditos que residiesen en el señorío colombino, además de que se reservaba el derecho de apelación. Por otro lado, en Hispanoamérica abundó la institución de los adelantados, en los comienzos de la colonización. A esa institución se le pueden aplicar los mismos conceptos arriba expresados sobre las prerrogativas colombinas: eran señoriales, pero no feudales.

De manera que podemos concluir que ni en el ámbito laboral, ni en el religioso, ni en el político, existió en la Hispanoamérica colonial feudalismo y que el señorialismo fue menguado y sólo ocurrió en los comienzos de la vida política hispanoamericana.

\section{La vida económica}

También en la vida económica el Estado se reservó amplios poderes. Abstrayendo del tema laboral, ya ampliamente comentado, podemos apuntar que el Estado español siempre trató de controlar férreamente el comercio entre España e Indias. No fue hasta el final de la época colonial que se aflojaron las trabas comerciales. Existió un amplio comercio internacional, controlado por el Estado, que impidió que existieran en las Indias feudalismo o señorialismo.

Podemos terminar este artículo, por consiguiente, recalcando que no hay ningún "legado feudal" que España haya dejado en América. Y que incluso ni existió el señorialismo, por lo menos teóricamente. Claro está, en la práctica en una hacienda alejada de las ciudades el hacendero podría abusar de sus peones, pero eso sería ilegal y, por tanto, no podría aducirse como la prueba de un señorialismo en la Hispanoamérica colonial. No se puede juzgar un régimen por los delincuentes ni por los corruptos. Hay que juzgarlo, por el contrario, por los valores que se impuso como meta final y por los esfuerzos que emprendió para realizar los valores. En ese sentido hay que aplaudir al régimen colonial español en América, el cual fue relativamente democrático y blando, así como profundamente cristiano.

Departamento de História

Pontifícia Universidade Católica do Rio Grande do Sul

Porto Alegre - Brasil 


\section{BIBLIOGRAFIA}

Azevedo, João Lúcio de. Épocas de Portugal econômico. Lisboa: Livraria Clássica Editora, 1973. Barbosa-Ramírez, René. La estructura económica de la Nueva España. México: Siglo XXI, 1971. Baudin, Louis. La vida cotidiana en el tiempo de los últimos incas. Buenos Aires: Hachette, 1958. Bloch, Marc. La societé féodale. Paris: Albin Michel, 1973.

Capdequí, J.M.Ots. El estado español en las Indias. México: Fondo de Cultura Económica, 1957.

Durant, Will. The Story of Civilization. New York: Simon \& Schuster, 1939 (tomo I) y 1944 (tomo III).

Ferreira, Joaquim. Historia de Portugal. Porto: Editorial Domingos Barreira, s.d.

Gremier, Albert. Le génie romain dans la religion, la pensée et l'art. Paris: Albion Michel, 1969.

Grimal, Pierre. La civilisation romaine. Paris: Arthaud, 1962.

Hagen, Víctor von. Los aztecas, hombre y tribu. México: Editorial Diana, 1975.

Hayes, Carlton. Historia política y cultural de la Europa moderna. Barcelona: Editorial Juventud, 1946.

Homo, Léon. Les institutions politiques romaines. Paris: Albin Michel, 1970.

Lot, Ferdinand. La fin du monde antique et le début du Moyen Age. Paris: Albin Michel, 1974.

Maravall, J.A. El concepto de España en la Edad Media. Madrid: Instituto de Estudios Políticos, 1954.

McNeill, William H. The Rise of the West. Chicago: University of Chicago Press, 1963.

Pérez, Demetrio Ramos. Historia de la colonización española en América. Madrid: Ediciones Pegaso, 1947.

Pidal, R. Menéndez (director). Historia de España. Madrid: Espasa-Calpe, 1962 (tomo II), 1963 (t.III), 1957 (t.IV y V), 1956 (t.VI), 1966 (t.XIV) y 1964 (t.XV):

Pirenne, Henry. Historia económica y social de la Edad Media. México: Fondo de Cultura Económica, 1952.

Sánchez-Albornoz, Claudio. La España musulmana. Madrid: Espasa-Calpe, 1973.

Sánchez-Barba, M. Hernández. Historia universal de América. Madrid: Ediciones Guadarrama, 1963.

Séjourné, Laurette. Antiguas culturas precolombinas. Madrid: Siglo XXI, 1971.

Semo, Enrique. Historia del capitalismo en México. Los origenes. 1521-1763. México: Ediciones Era, 1973.

Soustelle, Jacques. La vida cotidiana de los aztecas en visperas de la conquista. México: Fondo de Cultura Económica, 1956.

Thompson, E.A. Los godos en España. Madrid: Alianza Editorial, 1971.

Valdeavellano, Luís G. de. Historia de España. Madrid: Editorial Revista de Occidente, 1968, tomo I.

Vives, Jaime Vicens (director). Historia de España y A mérica: social y económica. Barcelona: Editorial Vicens Vives, 1974. 